\title{
KOMPOSISI KIMIA DAN AKTIVITAS ANTIOKSIDAN DARI PARING KELAPA (Cocos nucifera)
}

\author{
Meifry Gavrila Karepu ${ }^{*}$, Edi Suryanto ${ }^{1}$, Lidya Irma Momuat ${ }^{1}$ \\ ${ }^{1}$ Program Studi Kimia, Fakultas Matematika dan Ilmu Pengetahuan Alam \\ Universitas Sam Ratulangi Manado
}

\begin{abstract}
ABSTRAK
Penelitian ini bertujuan untuk mengkarakterisasi secara kimia dan menentukan aktivitas antioksidan dari paring kelapa yang diekstraksi dengan masing-masing pelarut petroleum eter (PPE) dan etanol (PET). Penelitian ini terdiri dari tiga tahap yaitu mikronisasi, karakterisasi, dan ekstraksi. Parameter yang digunakan adalah komposisi proksimat, serat kasar, serat pangan, kandungan hemiselulosa, selulosa, lignin, aktivitas antioksidan, dan kapasitas penangkal nitrit. Hasil karakterisasi secara kimia menunjukkan tepung paring kelapa yang diekstraksi dengan pelarut petroleum eter mengandung komposisi kimia seperti air $(6,99 \%)$, abu $(0,85 \%)$, lemak $(3,61 \%)$, protein $(10,39 \%)$, serat pangan tak larut $(78,27 \%)$, serat pangan terlarut $(2,66 \%)$, serat pangan total $(80,93 \%)$, hemiselulosa (25,38\%), selulosa (39,15\%) dan lignin (24,55\%). PET mengandung air (7,14\%), abu (1,03\%), lemak $(6,05 \%)$, protein $(9,85 \%)$, serat pangan tak larut $(73,795 \%)$, serat pangan terlarut $(2,53 \%)$, serat pangan total $(76,32 \%)$, hemiselulosa $(20,97 \%)$, selulosa $(35,14 \%)$ dan lignin $(32,07 \%)$. Hasil pengujian aktivitas antioksidan menunjukkan bahwa PET memiliki ekstrak fenolik bebas $(92,16 \%)$ tertinggi diikuti oleh ekstrak fenolik terikat PPE (87,75\%), ekstrak fenolik bebas PPE (85,07\%) dan ekstrak fenolik terikat PET (81,90\%).
\end{abstract}

Kata kunci: Karakterisasi, antioksidan, serat pangan, tepung paring kelapa

\begin{abstract}
The objectives of this research were to characterize the physicochemical properties and to determine the antioxidant activity of coconut testa dietary fiber. The research consisted of 3 stages: micronization, characterization, and extraction. The evaluate parameters were proximate composition, crude fiber, dietary fiber, hemicellulose, cellulose, lignin, antioxidant activity, and nitrate-scavenging capacity. Chemical characterization results showed that coconut testa powder has chemical compositions such as water $(6,99 \%)$, ash $(0,85 \%)$, fat $(3,61 \%)$, protein $(10,39 \%)$, carbohydrate $(48,75 \%)$, insoluble dietary fiber $(78,27 \%)$, soluble dietary fiber $(2,66 \%)$, total dietary fiber $(80,93 \%)$, hemicellulose $(25,38 \%)$, cellulose $(39,15 \%)$ and lignin $(24,55 \%)$. PET contains water $(7.14 \%)$, ash $(1.03 \%)$, fat $(6.05 \%)$, protein $(9.85 \%)$, insoluble food fiber $(73.795 \%)$, dissolved food fiber $(2.53 \%)$, total food fiber $(76.32 \%)$, hemicellulose $(20.97 \%)$, cellulose $(35.14 \%)$ and lignin $(32.07 \%)$. Antioxidant activity assay showed that free phenolic extract of PET had highest $(92.16 \%)$ followed by bound phenolic extract of PPE (87.75\%), free phenolic extract of PPE (85.07\%) and bound phenolic extract of PET (81.90\%).
\end{abstract}

Keywords: Characterization, antioxidant, dietary fiber, coconut testa powder

\section{PENDAHULUAN}

Kelapa (Cocos nucifera) adalah tanaman yang sangat banyak ditemukan di daerah tropis. Kelapa sangat popular di masyarakat karena memiliki banyak manfaat bagi kehidupan manusia. Bagian-bagian dari tanaman kelapa yang sering dimanfaatkan oleh masyarakat seperti buah, daging, akar, tempurung, batang dan daun (Pratiwi \& Sutara, 2013). Daging buah kelapa dapat diolah menjadi, minyak kelapa, kopra, santan kelapa dan tepung kelapa. Tiga butir kelapa dapat menghasilkan sekitar 1 kilogram limbah paring kelapa. Paring kelapa merupakan bagian dari buah kelapa berwarna cokelat dan

\footnotetext{
* Korespondensi:

Telepon: +62 821-9500-3707

Email: ririikarepu@gmail.com

DOI: https://doi.org/10.35799/cp.13.1.2020.29604
}

sering dibuang sehingga akan menjadi limbah padat (Risnita dkk., 2012).

Menurut Faizal dkk. (2011) ampas kelapa yang telah diperas santannya mengandung hemiselulosa, selulosa dan lignin sehingga limbah ampas kelapa disebut sebagai limbah lignoselulosa Bahan lignoselulosa mempunyai kandungan utama tiga macam polimer alam yang berbeda, yang dikenal dengan lignin, hemiselulosa, dan selulosa (Nadia dkk., 2011).

Putri (2014) melaporkan bahwa tepung ampas kelapa merupakan salah satu tepung sebagai sumber serat pangan dengan masingmasing nilai kandungan serat pangan tak larut sangat tinggi dan serat pangan larut sangat rendah yaitu $63,66 \%$ dan $4,53 \%$. Sedangkan menurut 
Muchsin dkk. (2016), santan dari kelapa yang berasal dari Sulawesi Utara berpotensi sebagai antioksidan alami. Antioksidan adalah senyawa yang diperlukan oleh manusia untuk menangkal radikal bebas di dalam tubuh. Serat pangan dan antioksidan merupakan dua jenis komponen yang sangat bermanfaat dalam meningkatkan aktivitas kesehatan dan mampu mencegah berbagai penyakit (Suryanto, 2018).

Menurut Wang dkk. (2012), sifat fungsional dari tepung antioksidan serat pangan berubah dengan adanya perubahan pada struktur dan karakteristik permukaan akibat perlakuan pengurangan ukuran partikel.

Saat ini penelitian mengenai serat pangan dari tepung paring kelapa belum banyak dilakukan. Oleh karena itu, peneliti tertarik mempelajari karakteristik fisikokimia dengan perlakuan ekstraksi menggunakan pelarut petroleum eter dan etanol serta aktivitas antioksidan tepung serat pangan dari paring kelapa (Cocos nucifera).

\section{BAHAN DAN METODE}

\section{Alat dan bahan}

Alat yang digunakan antara lain peralatan gelas, oven, timbangan analitik, alat untuk blender, penangas air, pipet volume, micro pipet, rotary evaporator, alat milling (Fomac tipe FCTZ200 tegangan $220 \mathrm{~V}$ daya $1 \mathrm{KW}$ frekuensi 50-60 $\mathrm{Hz}$ kecepatan putar $28.000 \mathrm{rpm}$ ), ayakan 35 dan 200 mesh, spektrofotometer UV-Vis. Bahan yang digunakan adalah sampel paring yang diperoleh dari PT. Trimustika Coco Minaesa (TMC), Amurang, Minahasa Selatan, kertas saring, akuades, petroleum eter, etanol, alumunium foil, kertas lakmus, natrium karbonat, reagen FolinCiocalteu, buffer fosfat, asam klorida, natrium hidroksida, asam sulfat, DPPH, N-(1naphthyl)ethylenediamine, asam sulfanilat, natrium nitrit, aseton, enzim $\alpha$-amilase, enzim amiloglukosidase.

\section{Preparasi}

Sampel paring dihancurkan dengan blender menggunakan air dan disaring untuk memisahkan filtrat dan ampas sebanyak 15 kali. Ampas paring yang diperoleh dikeringkan dalam oven pada suhu $55^{\circ} \mathrm{C}$ selama 24 jam dan dihaluskan menjadi bubuk kasar menggunakan blender. Bubuk kasar paring kelapa ditimbang masing-masing 20 gr disoxhletasi dengan masing-masing $300 \mathrm{~mL}$ pelarut petroleum eter dan etanol selama 6 jam.
Setelah itu tepung kasar diblender dan diayak dengan ayakan 35 mesh. Sampel paring yang lolos dari ayakan kemudian dihaluskan menggunakan alat milling Fomac tipe FCT-Z200 frekuensi $50-60 \mathrm{~Hz}$ dan diayak menggunakan ayakan 200 mesh $(75 \mu \mathrm{m})$. Tepung halus disimpan dalam wadah kedap udara dan disimpan di tempat yang sejuk, gelap, dan kering sebelum dilakukan analisis.

\section{Analisis komposisi kimia}

Analisis komposisi kimia paring kelapa meliputi kadar air, abu, lemak, dilakukan menurut prosedur Sudarmadji (1997). Untuk uji kadar air, tepung paring kelapa dikeringkan dalam oven selam 3 jam pada suhu $105{ }^{\circ} \mathrm{C}$ sampai berat konstan. Untuk uji kadar abu, tepung paring kelapa kering dibakar dalam tanur selama 4 jam pada suhu $650{ }^{\circ} \mathrm{C}$. Kandungan lemak ditentukan dengan mengekstraksi sampel menggunakan pelarut petroleum eter selama 4 jam pada peralatan soxhlet. Analisis protein dilakukan dengan metode SNI 01-2891-1992 butir 7.1.57. Semua parameter/komponen uji dilakukan 3 kali pengulangan.

\section{Penentuan serat pangan}

Kandungan serat pangan ditentukan menggunakan metode AOAC (1995). Sampel sebanyak $1 \mathrm{~g}$ dimasukkan ke dalam Erlenmeyer kemudian ditambahkan $25 \mathrm{~mL}$ larutan buffer fosfat $0,1 \mathrm{M} \mathrm{pH} 7$ dan diaduk agar terbentuk suspensi. Selanjutnya ditambahkan $0,1 \mathrm{~mL}$ enzim $\alpha$-amilase ke dalam Erlenmeyer yang berisi sampel. Erlenmeyer ditutup dengan aluminium foil dan diinkubasi dalam penangas air dengan suhu $100{ }^{\circ} \mathrm{C}$ selama 15 menit sambil diaduk sesekali. Sampel diangkat dan didinginkan lalu ditambahkan $20 \mathrm{~mL}$ aquades dan $5 \mathrm{~mL} \mathrm{NaOH} 1$ $\mathrm{N}$, kemudian ditambahkan enzim amiloglukosidase sebanyak $0,1 \mathrm{~mL}$. Erlenmeyer ditutup dan diinkubasi dalam penangas air bergoyang pada suhu $40{ }^{\circ} \mathrm{C}$ selama satu jam. Campuran disaring menggunakan kertas saring yang telah diketahui beratnya. Sampel dicuci dengan $2 \times 10 \mathrm{~mL}$ etanol dan $2 \times 10 \mathrm{~mL}$ aseton (dipisah). Sampel dikeringkan dalam oven pada suhu $105{ }^{\circ} \mathrm{C}$ selama satu malam lalu didinginkan dalam desikator (D1). Sampel kemudian diabukan dalam tanur pada suhu $525{ }^{\circ} \mathrm{C}$ selama minimal 5 jam, dan ditimbang setelah didinginkan dalam desikator untuk selanjutnya disebut serat pangan tak larut (IDF/insoluble dietary fiber). 
Filtrat diatur volumenya menjadi $100 \mathrm{~mL}$ dan ditambahkan $400 \mathrm{~mL}$ etanol $95 \%$ hangat. Filtrat dibiarkan mengendap selama 1 jam. Filtrat disaring dengan kertas saring bebas abu lalu dicuci dengan $2 \times 10 \mathrm{~mL}$ etanol dan $2 \times 10 \mathrm{~mL}$ aseton lalu dikeringkan semalam pada oven suhu $105{ }^{\circ} \mathrm{C}$ lalu dimasukkan ke dalam desikator. Dilakukan pengabuan dalam tanur $525^{\circ} \mathrm{C}$ selama minimal 5 jam, dan ditimbang setelah didinginkan dalam desikator untuk selanjutnya disebut serat pangan terlarut (SDF/soluble dietary fiber). Serat pangan total dihitung dengan menjumlahkan IDF dan SDF (Serat pangan total $=\mathrm{IDF}+\mathrm{SDF}$ ).

\section{Penentuan kadar hemiselulosa, selulosa, dan lignin}

Analisis kadar hemiselulosa, selulosa, lignin paring kelapa dilakukan dengan metode Datta (1981). Tepung halus paring kelapa ditimbang sebanyak 2 g (a) kemudian dimasukkan ke dalam gelas bekker, ditambah aquades sebanyak $150 \mathrm{~mL}$ dan dipanaskan pada penangas air pada suhu $100{ }^{\circ} \mathrm{C}$ selama 2 jam. Sampel yang sudah berbentuk bubur disaring kemudian dicuci dengan aquades sampai volume filtrat tepat $300 \mathrm{ml}$. residu dikeringkan dalam oven dengan suhu $105^{\circ} \mathrm{C}$ sampai mencapai berat konstan (b). Residu yang sudah kering dimasukkan dalam labu Erlenmeyer $250 \mathrm{ml}$, kemudian ditambah $150 \mathrm{~mL} \mathrm{H}_{2} \mathrm{SO}_{4} 1 \mathrm{~N}$ dan direfluk diatas penangas air pada suhu $100{ }^{\circ} \mathrm{C}$ selama 1 jam. Selanjutnya larutan disaring dan residu dicuci dengan aquades sampai volume filtrat mencapai $500 \mathrm{~mL}$ (netral). Residu dikeringkan dan ditimbang (c). Residu kering dimasukkan lagi ke dalam Erlenmeyer $250 \mathrm{~mL}$ ditambah $10 \mathrm{~mL} \mathrm{H}_{2} \mathrm{SO}_{4} 72 \%$ dan didiamkan selama 4 jam pada suhu kamar, kemudian ditambah $150 \mathrm{~mL} \mathrm{H}_{2} \mathrm{SO}_{4} 1 \mathrm{~N}$ dan direfluks pada pendingin balik pada suhu $100{ }^{\circ} \mathrm{C}$ selama 1 jam. Selanjutnya larutan disaring dan dicuci dengan air panas sampai netral (volume filtrat mencapai 400 ml). Residu dikeringkan dan ditimbang (d) dan selanjutnya diabukan dan ditimbang (e).

kadar hemiselulosa $=\frac{\mathrm{b}-\mathrm{c}}{\mathrm{a}} \times 100 \% \mathrm{~b} / \mathrm{b} \ldots$..(1)

kadar selulosa $=\frac{\mathrm{c}-\mathrm{d}}{\mathrm{a}} \times 100 \% \mathrm{~b} / \mathrm{b} \ldots$...(2)

kadar lignin $=\frac{\mathrm{d}-\mathrm{e}}{\mathrm{a}} \times 100 \% \mathrm{~b} / \mathrm{b} \ldots$..(3)

Keterangan: berat kering bahan (a), berat kering setelah diekstraksi dengan aquades (b), fraksi yang larut dalam $\mathrm{H}_{2} \mathrm{SO}_{4} 1 \mathrm{~N}$ (c), fraksi yang larut dalam $\mathrm{H}_{2} \mathrm{SO}_{4} 72 \%$ (d) dan kadar abu bahan (e).

\section{Ekstraksi}

Tepung paring kelapa dari hasil miling yang sudah di ayak dengan ayakan 200 mesh ditimbang sebanyak $5 \mathrm{~g}$ dimaserasi dengan $50 \mathrm{~mL}$ etanol $80 \%$ selama $1 \times 24$ jam kemudian disaring. Filtrat hasil maserasi dipekatkan menggunakan rotary evaporator dan ditimbang sebagai ekstrak fenolik bebas. Ampas dihidrolisis dengan $100 \mathrm{~mL}$ $\mathrm{NaOH} 2 \mathrm{M}$, diaduk dan diinkubasi pada suhu kamar selama 1 jam. Selanjutnya, campuran dinetralkan dengan $\mathrm{HCl}$ sampai $\mathrm{pH} 6$ dan diekstraksi sebanyak tiga kali dengan etil asetat sampai bening. Fraksi etil asetat dievaporasi pada $40{ }^{\circ} \mathrm{C}$ dan dikeringkan dalam oven sehingga didapat ekstrak fenolik terikat. Kedua ekstrak yang diperoleh ditimbang dan disimpan pada suhu $0{ }^{\circ} \mathrm{C}$ sebelum dianalisis kandungan total fenolik dan aktivitas antioksidan. Diagram alir ekstraksi fenolik bebas dan terikat disajikan pada lampiran 2.

\section{Penentuan kandungan total fenolik}

Kandungan total fenolik ditentukan menggunakan metode Jeong dkk. (2004). Sebanyak $0,1 \quad \mathrm{~mL}$ sampel $1000 \mu \mathrm{g} / \mathrm{mL}$ dimasukkan ke dalam tabung reaksi, lalu ditambahkan 0,1 mL reagen Folin Ciocalteu 50\% dalam tabung reaksi dan kemudian campuran divortex selama 3 menit. Setelah interval waktu 3 menit, ditambahkan $2 \mathrm{~mL}$ larutan $\mathrm{Na}_{2} \mathrm{CO}_{3} 2 \%$, kemudian campuran diinkubasi dalam ruang gelap selama 30 menit. Selanjutnya dibaca dibaca absorbansinya pada $\lambda 750 \mathrm{~nm}$ dengan menggunakan spektrofotometer UV-Vis.

\section{Aktivitas penangkal radikal bebas}

Penentuan aktivitas penangkal radikal bebas tepung paring kelapa ditentukan dengan metode Burda \& Oleszeck (2001). Sebanyak 0,5 $\mathrm{mL}$ masing-masing ekstrak ditambahkan dengan 1,5 mL larutan DPPH dan divortex selama 2 menit. Berubahnya warna larutan dari ungu ke kuning menunjukan efisiensi penangkal radikal bebas. Selanjutnya pada 5 menit terakhir menjelang 30 menit inkubasi, absorbansinya diukur pada panjang gelombang $517 \mathrm{~nm}$ dengan menggunakan spektrofotometer UV-VIS. Aktivitas penangkal radikal bebas (APRB) dihitung sebagai presentase berkurangnya warna DPPH dengan menggunakan persamaan:

$$
\text { APRB }=\left(1-\frac{\text { absorbansi sampel }}{\text { absorbansi kontrol }}\right) \times 100 \%
$$




\section{Kapasitas penangkal nitrit}

Kapasitas penangkal nitrit ditentukan menggunakan metode Zhang dkk. (2009). $2 \mathrm{~mL}$ Natrium nitrit $5 \mathrm{mg} / \mathrm{L}$ dicampur dengan $3 \mathrm{~mL}$ ekstrak dalam labu $25 \mathrm{~mL}$ pada suhu kamar selama 30 menit. Larutan campuran dicampur dengan $1 \mathrm{~mL}$ asam sulfanilat $0,4 \%$ distirer selama 5 menit diikuti penambahan $0,5 \mathrm{~mL} \mathrm{~N}$-(1Naphthyl)ethylenediamine $0,1 \%$ dan volume disesuaikan menjadi $25 \mathrm{~mL}$ dengan aquades. Larutan didiamkan selama 15 menit dan diukur absorbansi menggunakan Spektrofotometer UVVis pada $\lambda 538 \mathrm{~nm}$. Persentase kapasitas penangkal ion nitrit (KPIN) dihitung menggunakan rumus:

$$
\operatorname{KPIN}(\%)=\left(\frac{\mathrm{A}_{0}-\left(\mathrm{A}_{1}-\mathrm{A}_{2}\right)}{\mathrm{A}_{0}}\right) \times 100 \%
$$

Keterangan: $\quad \mathrm{A}_{0}=$ Absorbansi $\mathrm{NaNO}_{2} ; \mathrm{A}_{1}=$ Absorbansi $\mathrm{NaNO}_{2}$ dan Ekstrak; $\mathrm{A}_{2}=$ Absorbansi ekstrak

\section{HASIL DAN PEMBAHASAN}

\section{Rendemen paring kelapa}

Sampel yang digunakan dalam penelitian ini adalah paring kelapa. Paring kelapa yang berwarna coklat dipisahkan dari daging kelapa yang berwarna putih. Selanjutnya paring kelapa diblender menggunakan air dan disaring sebanyak 15 kali untuk mengurangi kadar santan dalam sampel sekaligus untuk menghancurkan sampel. Setelah pengeringan sampel disoxhletasi. Tujuannya untuk mengurangi lemak yang terdapat pada paring kelapa sehingga paring kelapa yang telah digiling mudah diayak.

Berdasarkan penelitian nilai rendemen paring yang diekstraksi menggunakan pelarut etanol dan petroleum eter berturut-turut adalah $88,26 \%$ dan $83,48 \%$. Hal ini mungkin disebabkan pelarut petroleum eter yang merupakan pelarut non-polar dapat melarutkan lebih banyak komponen non-polar seperti lemak. Sedangkan pelarut etanol lebih banyak melarutkan komponen polar seperti karbohidrat. Proses soxhletasi menggunakan dua jenis pelarut dengan tingkat kepolaran berbeda yaitu pelarut petroleum eter (non-polar) dan etanol (polar). Penggunaan pelarut etanol karena merupakan pelarut universal, pelarut ini dapat melarutkan hampir semua senyawa organik yang ada pada sampel, baik senyawa polar maupun senyawa non polar (Noviyanti, 2016).

\section{Mikronisasi paring kelapa}

Pada penelitian ini sampel PPE dan PET dilakukan mikronisasi untuk memperoleh sampel berbentuk tepung. Teknik mikronisasi yang digunakan yaitu penggilingan dengan alat milling Fomac tipe FCT-Z200 frekuensi 50-60 Hz secara berulang kemudian diayak dengan ayakan 200 mesh untuk memperoleh tepung PPE dan PET. Pengayakan dilakukan menggunakan 200 mesh bertujuan untuk memperoleh hasil pengujian maupun hasil ekstraksi yang baik. Menurut Sembiring dkk. (2006), semakin halus bahan membuat proses ekstraksi berlangsung dengan baik dan tidak memakan waktu yang lama.

Berdasarkan penelitian rendemen tepung dengan ukuran 200 mesh dari sampel PPE yaitu $80,11 \%$ dan PET $75,66 \%$. PPE memiliki rendemen lebih tinggi dari pada PET. Hal ini diduga karena pelarut petroleum eter dikenakan pada PPE lebih banyak mengekstraksi lemak dari pada PET. Sedangkan pelarut etanol lebih banyak melarutkan komponen polar seperti fenolik. Etanol dapat melarutkan senyawa dari yang kurang polar hingga polar, salah satu senyawa yang dapat dilarutkan oleh etanol ialah senyawa fenolik sedangkan petroleum eter adalah pelarut non polar yang bersifat mudah menguap (Romadanu dkk., 2013; Lifton, 2007).

\section{Komposisi kimia PPE dan PET}

Hasil analisis proksimat tepung paring kelapa yang merupakan hasil rata-rata dari tiga kali pengulangan diperlihatkan pada Tabel 1 . Tepung paring kelapa yang diekstraksi dengan pelarut petroleum eter (PPE) memiliki kandungan nutrisi berturut-turut karbohidrat total $48,80 \%$, lemak total 3,61\%, protein total 9,85\%, kadar abu (mineral total) $0,85 \%$, dan kadar air 6,99\%. Sedangkan tepung paring kelapa yang diektraksi dengan pelarut etanol (PET) memiliki kandungan nutrisi berturut-turut karbohidrat total $49,42 \%$, lemak total $6,05 \%$, protein total $10,39 \%$, kadar abu (mineral total) 1,03\%, dan kadar air 7,14\%.

Berdasarkan data pada Tabel 1, kadar air pada PET lebih tinggi dibandingkan pada PPE. Hal ini mungkin disebabkan karena residu hasil soxhlet menggunakan pelarut etanol bersifat polar sehingga kadar air dari ampas paring yang diekstraksi dengan etanol yang dihasilkan lebih bersifat polar. Penelitian Atisanto dkk. (2017) menunjukkan bahwa pelarut polar menunjukkan kadar air lebih tinggi dari pada pelarut non-polar. 
Tabel 1. Hasil analisis komposisi proksimat tepung paring kelapa

\begin{tabular}{lll}
\hline \multicolumn{1}{c}{$\begin{array}{c}\text { Jenis } \\
\text { Komposisi }\end{array}$} & \multicolumn{1}{c}{ PPE } & \multicolumn{1}{c}{ PET } \\
\hline Air & $6,99 \pm 0,39^{\mathrm{a}}$ & $7,14 \pm 0,24^{\mathrm{a}}$ \\
Abu & $0,85 \pm 0,08^{\mathrm{a}}$ & $1,03 \pm 0,09^{\mathrm{b}}$ \\
Lemak & $3,61 \pm 0,26^{\mathrm{a}}$ & $6,05 \pm 0,17^{\mathrm{b}}$ \\
Protein & $10,39 \pm 0,05^{\mathrm{a}}$ & $9,85 \pm 0,08^{\mathrm{b}}$ \\
SP Tak Larut & $78,27 \pm 0,05^{\mathrm{a}}$ & $73,79 \pm 0,12^{\mathrm{b}}$ \\
SP Terlarut & $2,66 \pm 0,02^{\mathrm{a}}$ & $2,53 \pm 0,29^{\mathrm{a}}$ \\
SP Total & $80,93 \pm 0,08^{\mathrm{a}}$ & $76,32 \pm 0,41^{\mathrm{b}}$ \\
\hline
\end{tabular}

Keterangan: Ampas paring yang diekstraksi dengan petroleum eter (PPE), Ampas paring yang diekstraksi dengan etanol (PET), Serat pangan (SP). Huruf yang berbeda di belakang angka menunjukkan perbedaan signifikansi

Hasil analisis statistik menujukkan masingmasing jenis perlakuan pada sampel berpengaruh nyata terhadap kadar abu $(\mathrm{p}<0,05)$. Tingginya kadar abu pada PET dan PPE karena komponen organiknya telah banyak ditarik oleh pelarut yang digunakan saat soxhletasi. Sehingga perlakuan dengan pelarut dapat mempengaruhi kadar abu. Kadar abu berhubungan dengan kandungan mineral suatu bahan. Semakin tinggi kadar abu maka semakin tinggi pula kadar mineral dalam bahan pangan tersebut (Winarno, 1992).

Hasil analisis statistik menunjukkan adanya pengaruh nyata pada kadar lemak dari keempat jenis sampel dengan perlakuan berbeda $(\mathrm{p}<0,05)$. Kadar lemak pada PET lebih tinggi dari pada PPE. Kadar lemak ini merupakan sisa kandungan lemak pada tepung paring kelapa setelah disoxhlet. Rendahnya kadar lemak PPE karena petroleum eter memiliki tingkat kepolaran yang sama dengan lemak sehingga pelarut petroleum eter melarutkan lebih banyak komponen non-polar seperti lemak. Hal ini sesuai dengan teori Kusnandar (2010), bahwa lemak yang non-polar hanya dapat larut pada pelarut non-polar seperti petroleum eter, heksana, dan kloroform.

Hasil analisis statistik menujukkan masingmasing jenis perlakuan pada sampel berpengaruh nyata terhadap kandungan protein $(\mathrm{p}<0,05)$. Pada penetlitian ini kadar protein PPE lebih tinggi dari pada PET. Tingginya kadar protein PPE karena protein yang bersifat tidak larut dalam eter. Menurut Devi (2010), protein dapat bereaksi dengan asam dan basa namun semua protein tidak dapat larut dalam pelarut lemak seperti eter dan kloroform.
Berdasarkan Tabel 1, kandungan serat pangan total pada PPE sebesar $80,93 \%$ yang terdiri dari serat pangan tak larut $78,27 \%$ dan serat pangan terlarut 2,66\% sedangkan PET sebesar $76,32 \%$ yang terdiri dari serat pangan tak larut $73,79 \%$ dan serat pangan terlarut 2,53\%. Hasil analisis statistik menujukkan masingmasing jenis perlakuan pada sampel berpengaruh nyata terhadap kadar serat tak larut. Sedangkan pada serat terlarut, jenis pelarut yang digunakan tidak berpengaruh nyata terhadap komponen serat pangan terlarut. Kandungan serat pangan pada PPE lebih tinggi dari pada PET. Tingginya serat pangan pada PPE mungkin disebabkan oleh lebih banyaknya komponen karbohidrat yang ikut terekstrak oleh pelarut etanol sehingga nilai PET lebih rendah daripada PPE. Karbohidrat memiliki sifat yang mudah larut dalam pelarut polar dan kurang larut dalam pelarut non-polar (Stryer, 2000).

\section{Kandungan hemiselulosa, selulosa dan lignin}

Hasil analisis kandungan hemiselulosa, selulosa dan lignin dari tepung paring kelapa ditunjukkan pada Tabel 2.

Tabel 2. Kandungan hemiselulosa, selulosa dan lignin tepung paring kelapa

\begin{tabular}{lcc}
\hline \multirow{2}{*}{ Kandungan } & \multicolumn{2}{c}{ Sampel } \\
\cline { 2 - 3 } & PPE & PET \\
\cline { 2 - 3 } Hemiselulosa (\%) & $25,38 \pm 0,24^{\mathrm{a}}$ & $20,97 \pm 0,30^{\mathrm{b}}$ \\
Selulosa (\%) & $39,15 \pm 0,10^{\mathrm{a}}$ & $35,14 \pm 0,41^{\mathrm{b}}$ \\
Lignin (\%) & $24,55 \pm 0,12^{\mathrm{a}}$ & $32,07 \pm 0,38^{\mathrm{b}}$ \\
\hline
\end{tabular}

Berdasarkan Tabel 2, diperoleh kandungan hemiselulosa, selulosa dan lignin pada PPE secara berturut-turut adalah $25,38 \%, 39,15 \%, 24,55 \%$ dan pada PET 20,97\%, 35,14\%, 32,07\%. Hasil menunjukkan tepung paring kelapa PPE memiliki kandungan hemiselulosa dan selulosa yang lebih besar dari pada PET sedangkan komponen lignin ditemukan paling besar pada PET. Rendahnya selulosa pada PET diduga karena gugus hidroksil bebas pada selulosa yang dapat membentuk ikatan hidrogen dengan molekul etanol yang kemudian menyebabkan pelarut etanol banyak menarik komponen polar yang menurunkan kandungan selulosa pada PET. Dalam fibril selulosa tersebar bentuk kristalin dan amorf selulosa secara acak. Bentuk amorf memiliki rantai pendek dan ikatan hidrogen antar molekul yang rendah (Murti, 2017).

Kadar hemiselulosa pada PET lebih rendah dari pada PPE. Hal ini diduga karena adanya gugus $\mathrm{OH}$ pada hemiselulosa menyebabkan 
terjadinya sifat polar pada hemiselulosa yang kemungkinan berinteraksi dengan etanol yang polar. Menurut Nurhayati \& Sutrisno (2012), adanya gugus $\mathrm{OH}$ pada hemiselulosa menyebabkan terjadinya sifat polar sehingga hemiselulosa lebih kuat menyerap komponen yang bersifat polar dari pada komponen nonpolar. Menurut Ilmiati dkk. (2018) lignin memiliki bagian polar dan non-polar karena cincin benzene dan gugus hidroksilnya. Kadar lignin pada PET lebih tinggi dari pada PPE. Hal ini diduga pelarut petroleum eter dapat melarutkan komponen non-polar pada PPE temasuk bagian non polar lignin. Hasil analisis ragam menunjukkan jenis pelarut memberikan pengaruh yang nyata terhadap komponen serat pangan tak larut hemiselulosa, selulosa, dan lignin $(\mathrm{p}<0,05)$. Dari dua variable memperlihatkan bahwa kandungan selulosa pada tepung paring kelapa yang paling tinggi dibandingkan dengan komponen serat pangan tak larut lainnya.

\section{Rendemen ekstraksi tepung paring kelapa}

Metode ekstraksi yang dilakukan dalam penelitian ini adalah ekstraksi secara maserasi dan hidrolisis dengan asam dan basa. Ekstraksi PPE dan PET dengan pelarut etanol digunakan untuk mendapatkan ekstrak fenolik bebas sedangkan residu hasil ekstraksi fenolik bebas dihidrolisis dengan asam dan basa untuk mendapatkan ekstrak fenolik terikat. Hasil rendemen dari kedua metode ekstraksi tersebut dari PPE dan PET dapat dilihat pada Tabel 3.

Tabel 3. Rendemen dan ekstraksi masing-masing ekstrak

\begin{tabular}{clc}
\hline Sampel & \multicolumn{1}{c}{ Ekstrak } & Rendemen (\%) \\
\hline PET & Fenolik bebas & 31,4 \\
& Fenolik terikat & 24,5 \\
PPE & Fenolik bebas & 57,3 \\
& Fenolik terikat & 34,9 \\
\hline
\end{tabular}

Dari data yang dapat dilihat pada Tabel 3, dapat diketahui bahwa PET memperoleh presentase rendemen yang lebih tinggi dari pada PPE. Tingginya nilai rendemen EFT (Ekstrak Fenolik Terikat) mengindikasikan bahwa paring kelapa memiliki banyak komponen senyawa metabolit sekunder yang tidak terekstraksi hanya dengan metode ekstraksi maserasi. Hal ini diduga karena adanya ikatan glikosidik yang menyebabkan senyawa fenolik tidak mudah untuk diekstraksi dengan pelarut. Sedangkan ekstraksi dengan hidrolisis yang menggunakan asam dan basa dapat memutuskan ikatan antara senyawa fenolik dengan karbohidrat. Penggunaan pelarut etil asetat untuk mengekstrak senyawa metabolit sekunder yang tersisa pada residu ekstrak fenolik bebas. Penggunaan pelarut etil asetat dapat melarutkan lebih banyak senyawa fenolik yang bersifat semipolar (Harborne, 1987). Semakin besar rendemen semakin banyak senyawa aktif yang terekstrak. Menurut Harmita (2008), perendaman sampel melalui metode maserasi akan memecah dinding sel dan pelarut masuk ke dalam rongga sel yang mengandung zat-zat aktif sehingga zat aktif akan mudah larut. Pelarut yang digunakan dalam penelitian ini adalah pelarut etanol $80 \%$ karena pelarut ini bersifat polar, universal dan food grade. Pelarut polar yang digunakan bertujuan untuk mengambil komponen polar seperti senyawa fenolik.

\section{Kandungan total fenolik ekstrak tepung paring kelapa}

Senyawa fenolik merupakan zat pada tumbuhan yang memiliki gugus aromatic dengan satu atau lebih gugus -OH (Harborne, 1993). Pada penelitian ini kandungan fenolik dtentukan dengan secara spektrofotometri dengan reagen Folin-Ciocalteu. Metode ini memiliki banyak keuntungan yaitu sederhana, dapat diulang, hasil yang akurat, dan telah digunakan secara luas (Berker dkk., 2013). Kandungan total fenolik masing-masing sampel dinyatakan sebagai ekuivalen asam galat atau Gallic Acid Equivalent (GAE). Hasil analisis kandungan fenolik tepung paring kelapa ditunjukkan pada Tabel 4.

Tabel 4. Kandungan total fenolik tepung paring kelapa

\begin{tabular}{clc}
\hline Sampel & \multicolumn{1}{c}{ Ekstrak } & Total fenolik $(\mu \mathrm{g} / \mathrm{mL})$ \\
\hline PET & Fenolik bebas & $162,52 \pm 0,01^{\mathrm{a}}$ \\
& Fenolik terikat & $127,16 \pm 0,01^{\mathrm{d}}$ \\
PPE & Fenolik bebas & $40,02 \pm 0,04^{\mathrm{b}}$ \\
& Fenolik terikat & $90,6 \pm 0,04^{\mathrm{c}}$ \\
\hline
\end{tabular}

Berdasarkan Tabel 4 dapat diketahui bahwa kandungan fenolik tertinggi terdapat pada ekstrak fenolik bebas PET sebesar 162,52 $\mu \mathrm{g} / \mathrm{mL}$, diikuti ekstrak fenolik terikat PET 127,16 $\mu \mathrm{g} / \mathrm{mL}$, ekstrak fenolik terikat PPE 90,6 $\mu \mathrm{g} / \mathrm{mL}$, dan yang terakhir yaitu ekstrak fenolik bebas PPE 40,02 $\mu \mathrm{g} / \mathrm{mL}$. Hasil uji statistik menunjukkan bahwa terdapat perbedaan nyata dari masing-masing 
ekstrak $(\mathrm{p}<0,05)$ terhadap kandungan fenolik. Total fenolik dari PET lebih tinggi dari pada PPE. PET yang telah diekstraksi dengan pelarut etanol memiliki kandungan fenolik yang paling tinggi. Hal ini diduga karena pelarut etanol yang bersifat polar mempengaruhi ikatan hidrogen antara molekul karbohidrat dengan senyawa fenolik dalam tepung paring kelapa membuat senyawa fenolik lebih mudah diekstrak. Tingginya fenolik terikat PPE mengindikasikan adanya kandungan fenolik terikat yang besar dalam PPE karena pelarut petroleum eter yang bersifat non-polar tidak dapat melarutkan komponen fenolik dan molekul pelarut terjepit diantara permukaan serat sehingga senyawa fenolik tidak mudah diekstrak dengan ekstraksi secara maserasi. Menurut Parra dkk. (2007) senyawa fenolik terikat yang tinggi mengindikasikan residu hasil ekstrak fenolik bebas masih banyak mengandung senyawa fenolik. Semakin banyak gugus fenolik maka semakin besar konsentrasi fenolik yang terdeteksi (Khadambi, 2007).

\section{Kemampuan penangkal radikal bebas}

Kemampuan penangkal radikal bebas dari ekstrak fenolik PPE dan PETA disajikan pada Tabel 5.

Tabel 5. Aktivitas penangkal radikal bebas dari berbagai ekstrak tepung paring kelapa

\begin{tabular}{clc}
\hline Sampel & \multicolumn{1}{c}{ Ekstrak } & $\begin{array}{c}\text { Aktivitas penangkal } \\
\text { radikal bebas }(\%)\end{array}$ \\
\hline PET & Fenolik bebas & $92,16 \pm 0,021^{\mathrm{a}}$ \\
& Fenolik terikat & $81,90 \pm 0,01^{\mathrm{b}}$ \\
PPE & Fenolik bebas & $85,07 \pm 0,01^{\mathrm{c}}$ \\
& Fenolik terikat & $87,75 \pm 0,01^{\mathrm{c}}$ \\
\hline
\end{tabular}

Ket: $\quad$ PPE $=$ Paring yang diekstraksi dengan petroleum eter; PET = Paring yang diekstraksi dengan etanol.

Berdasarkan Tabel 5, ekstrak fenolik bebas PET memberi hasil paling tinggi yaitu $92,16 \%$ diikuti oleh ekstrak fenolik bebas PPE 87,75\%, ekstrak fenolik terikat PPE 85,07\%, dan ekstrak fenolik terikat PET $81,89 \%$. Hasil uji statistik menunjukkan terdapat pengaruh nyata dari ekstrak fenolik bebas PET dan terikat PPE terhadap aktivitas penangkal radikal bebas. Sedangkan fenolik bebas PPE dan ekstrak fenolik terikat PET tidak berpengaruh nyata terhadap aktivitas antioksidan. Ekstrak fenolik PET menunjukkan aktivitas penangkal radikal bebas yang paling tinggi. Tingginya aktivitas antioksidan PET kemungkinan karena pelarut etanol tidak banyak menghilangkan komponen fenolik saat ekstraksi secara soxhlet. Sedangkan aktivitas antioksidan PPE yang rendah diduga karena adanya antioksidan non-polar seperti tokoferol yang terkandung dalam tepung paring kelapa yang terekstrak dengan pelarut petroleum eter. Tokoferol sebagai antioksidan menyumbangkan hidrogen fenolik ke lipid radikal bebas dan menghambat proses peroksidasi (Martha dkk., 2013). Dari data di atas dapat disimpulkan bahwa ekstrak fenolik bebas dan ekstrak fenolik terikat sama-sama memiliki kemampuan aktivitas antioksidan yang sangat baik.

\section{Kapasitas penangkal nitrit}

Hasil analisis kapasitas penangkal nitrit dari ekstrak fenolik tepung paring kelapa masingmasing disajikan pada Tabel 6.

Tabel 6. Kapasitas penangkal nitrit dari berbagai ekstrak tepung paring kelapa

\begin{tabular}{ccc}
\hline Sampel & Ekstrak & KPN $(\%)$ \\
\hline PET & Fenolik bebas & $55,05 \pm 0,02^{\mathrm{a}}$ \\
& Fenolik terikat & $56,93 \pm 0,03^{\mathrm{a}}$ \\
PPE & Fenolik bebas & $42,46 \pm 0,0007^{\mathrm{b}}$ \\
& Fenolik terikat & $41,25 \pm 0,008^{\mathrm{b}}$ \\
\hline
\end{tabular}

Berdasarkan Tabel 6, kapasitas penangkal nitrit (KPN) ekstrak fenolik bebas PET 55,05\%, PPE 42,46\%, ekstrak fenolik terikat PET 56,93, PPE $41,25 \%$. Berdasarkan analisis ragam tidak terdapat perbedaan nyata untuk kapasitas penangkal nitrit dari ekstrak fenolik bebas dan fenolik terikat dari masing-masing sampel PET dan PPE namun terdapat perbedaan nyata dalam kapasitas penangkal nitrit dari kedua perlakuan pelarut yang berbeda. Hasil analisis menunjukkan ekstrak fenolik PET memiliki KPN lebih tinggi dari pada ekstrak fenolik PPE. Rendahnya KPN ekstrak fenolik PPE kemungkinan karena adanya senyawa fenolik pada ekstrak yang bersifat prooksidan berinteraksi dengan radikal nitrit mempercepat proses oksidasi lipid. Prooksidan merupakan sifat senyawa yang dapat mendorong oksidasi pada komponen sel yang melibatkan senyawa radikal bebas (Skrzdlewska dkk., 2004). Senyawa prooksidan ini menimbulkan radikal bebas yang mendorong peroksidasi lipid (Yomes, 2006). 


\section{KESIMPULAN}

Hasil karakterisasi secara kimia menunjukkan komposisi kimia seperti air, abu, lemak, protein, karbohidrat, dan lignin dari PPE lebih rendah dari pada PET. Sedangkan komposisi protein, serat kasar, serat pangan tak larut, serat pangan terlarut, serat pangan total, hemiselulosa dan selulosa dari PPE lebih tinggi dari pada PET. Hasil pengujian aktivitas antioksidan menunjukkan bahwa baik ekstrak fenolik terikat maupun ekstrak fenolik bebas dari PET memiliki aktivitas antioksidan yang lebih tinggi dari ekstrak fenolik terikat maupun ekstrak fenolik bebas PPE.

\section{DAFTAR PUSTAKA}

Abbasi, M.A., Islam, M., Aziz-ur-Rehman, Rasool, S., Rubab, K., Hussain, G., Ahmad, I., Ahsraf, M., Shadid, M. \& Shah, S.A.A. 2016. Synthesis, Characterization, Antibacterial, $\alpha$ Glucosidase Inhibition and Hemolytic Studies on Some New N-(2,3Dimethylphenyl)benzenesulfonamide Derivatives. Tropical Journal of Pharmaceutical Research. 15(3), 591598.

AOAC. 1995. Official methods of analysis (16th ed.). AOAC International, Washington.

Burda, S. \& Oleszek, W. 2001. Antioxidant and antiradical activities of flavonoids. Journal of Agricultural and Food Chemistry. 49(6), 2774-2779.

Cadden, A-M. 2006. Comparative effects of particle size reduction on physical structure and water binding properties of several plant fibers. Journal of Food Science. 52(6), 1595-1599.

Chau C.F., Wang, Y.T. \& Wen, Y.L. 2007. Different micronization methods significantly improve the functionality of carrot insoluble fibre. Food Chemistry. 100(4), 1402-1408.

Datta, R. 1981. Acidogenic fermentation of lignocelluloses acid yield and convertion of componens. Biotechnology and Bioengineering. 23(9), 2167-2170.

Faizal, M., Zuhandri \& Andrio, I. 2011. Pengaruh massa ragi dan lama fermentasi terhadap pembentukan etanol dari ampas kelapa. Jurnal Teknik. 17(8), 8-18.
Jeong, S.M., S.Y. Kim, D.R. Kim, S.C. Jo, K.C. Nam, D.U. Ahn \& S.C. Lee. 2004. Effect of heat treatment on the antioxidant activity of extracts from citrus peels. Journal of Agricultural and Food Chemistry. 52(11), 3389- 3393.

Liu, C. \& Bai, R. 2005. Preparation of chitosan/cellulose acetate blend hollow fibers for adsorptive performance. Journal of Membrane Science. 267(1-2), 68-77.

Liu, Y., Wang, L., Liu, F. \& Pan, S. 2016. Effect grinding methods on structural, physicochemical, and functional properties of insoluble dietary fiber from orange peel. International Journal of Polymer Science. 2016, 1-7.

Milovanovic, S., Markovic, D., Aksentijevic, K., Stojanovic, D.B., Ivanovic, J. \& Zizovic, I. 2016. Application of cellulose acetate for controlled release of thymol. Carbohydrate Polymers. 147, 344-353.

Moran, J.I., Alvarez, V.A., Cyras, V.P. \& Vasquez, A. 2008. Extraction of cellulose andpreparation of nanocellulose from sisal fibers. Cellulose. 15(1), 149-159

Muchsin, R., Fatimah, F. \& Rorong J. 2016. Aktivitas antioksidan dari santan kelapa di Sulawesi Utara. Chemistry Progress. 9(2), 48-52.

Mukhriani. 2014. Ekstraksi, pemisahan senyawa dan identifikasi senyawa aktif. Jurnal Kesehatan. 7(2), 361 - 367.

Nadia, A., Fauziah, A., Mayori, E., \& Sunardi. 2017. Potensi limbah lignoselulosa kelapa sawit di Kalimantan Selatan untuk produksi bioetanol dan xylitol. Jurnal Inovasi Pendidikan Sains. 8(2), 45-51.

Parra, L.D.C., Saldivar, S.O.S . \& Liu, H.R . 2007. Effec of processing on the photochemical profile and antioxidant activity of corn for production of masa, tortillas, and tortilla chips. Journal of Agicultural and Food Chemistry. 55(10), 4177-4183.

Pratiwi, M.F. \& Sutara, P.K. 2013. Etnobotani kelapa (Cocos nucifera L.) di wilayah Denpasar dan Badung. Jurnal Simbiosis. 1(2), 102-111.

Putri, M.F. 2014. Kandungan gizi dan sifat fisik tepung ampas kelapa aebagai bahan pangan sumber serat. TEKNOBUGA. 1(1), 32-43.

Raharja, S., Paryanto, I. \& Yuliani, F. 2010. Ekstraksi dan analisa dietary fiber dari 
buah mengkudu (Morinda citrifolia). Jurnal Teknologi Industri. 14(1), 30-39

Rakhmawati, N., Amanto, B.S. \& Praseptiangga, D. 2014. Formulasi dan evaluasi sifat sensoris dan fisikokimia produk flakes komposit berbahan dasar tepung tapioka, tepung kacang merah (Phaseolus vulgaris L.) dan tepung konjac (Amorphophallus oncophillus). Jurnal Teknosains Pangan. 3(1), 63-73.

Risnita, E.N., Muryoto \& Herawati, L. 2012. Fermentasi yuyu (Paratelphusa) sebagai penghasil minyak dari limbah kulit ari kelapa. Jurnal Teknologi Kesehatan. 8(4), 217-222.

Romadanu, Rachmawati, S.H. \& Lestari, S.D. 2014. Pengujian aktivitas antioksidan ekstrak bunga lotus. Fishtec. 3(1), 1-7.

Saputra, T.R., Ngatin, A. \& Sarungu, Y.T. 2018. Penggunaan metode ekstraksi maserasi dan partisi pada tumbuhan cocor bebek (Kalanchoe pinnata) dengan kepolaran berbeda. Fullerene Journal of Chemistry. 3(1), 5-8.

Sembiring, B. B., Ma'mun \& Ginting, E.I. 2006. Pengaruh kehalusan bahan dan lama ekstraksi terhadap mutu ekstrak temulawak. Buletin Penelitian Tanaman Rempah dan Obat. 17(2), 53-58.

Shanmugarajah, B., Kiew, P.L., Chew, I.M.L. \& Choong, T.S.Y. 2015. Isolation of nanocrystalline cellulose (NCC) from palm oil empty fruit bunch (EFB), preliminary result on FTIR and DLS Analysis. Chemical Engineering Transactions. 45, 1705-1710.

Skrzydlewska, E., Ostrowska, J., Luczaj, W., Kasacka, I. \& Rozanski, A. 2004. Green tea against ethanol-induced lipid peroksidasi in rat organs. Journal of Clinical Medicine. 32(1), 25-32.
Sudarmadji. 1996. Prosedur analisa untuk bahan makanan dan pertanian. Liberty, Yogyakarta.

Sun, X.F., Sun, R.C., Fowler, P. \& Baird, M.S. 2004. Isolation and characterization of cellulose obtained by a two-stage treatment with organosolv and cyanamide activated hydrogen peroxide from wheat straw. Carbohydrate Polymers. 55(4), 379-391.

Suryanto, E. \& Wehantouw, F. 2009. Aktivitas penangkap radikal bebas dari ekstrak fenolik daun sukun (Artocarpus altili F.). Chemistry Progress. 2(1), 1-7.

Suryanto, E. 2018. Kimia antioksidan. CV. Patra Media Grafindo, Bandung.

Wang, T., Sun, X., Zhou, Z. \& Chen, G. 2012. Effects of microfluidization process on physicochemical properties of wheat bran. Food Research International. 48(2), 742-747.

Zhang, L., Xu, H. \& Li, S. 2009. Effects of micronization on properties of Chaenomeles Sinensis (Thouin) Koehne fruit powder. Innovative Food Science \& Emerging Technologies. 10(4), 633-637.

Zhao, X.Y., Chen, J. \& Chen, F.L., 2013. Surface Characterization of Corn Stalk Superfine Powder Studied by FTIR and XRD. Colloids and Surfaces B: Biointerfaces. 104, 207-212. 